\title{
Zoning and Eminent Domain Under the New Minimum Scrutiny
}

\author{
by John Ryskamp
}

Recently the Supreme Court has made it clearer that minimum scrutiny is a factual analysis. Whether in any government action there is a rational relation to a legitimate interest is a matter of determining whether there is a policy maintaining important facts. This has come about in the Court's emerging emphasis on developing fact-based criteria for determining government purpose. Thus, those who want to affect zoning and eminent domain outcomes should look to what the Court sees as important facts, and whether government action is maintaining those facts.

The leading land use case is a takings case. It held zoning to be constitutional: Village of Euclid, Ohio v. Ambler Realty Co., 272 US 365 (1926). The question for the Euclid Court was, whether zoning violates " "the right of property...by attempted regulations under the guise of the police power, which are unreasonable and confiscatory'?" The Euclid Court set up certain facts as important and then sustained the zoning law at issue (a single-family land use law) because it maintained the facts. Maintenance-what it is and what it maintains-are what mattered to the Court. The Court saw housing as what was maintained in the case: "The serious question in the case arises over the provisions of the ordinance excluding from residential districts apartment houses, business houses, retail stores and shops, and other like establishments. This question involves the validity of what is really the crux of the more recent zoning legislation, namely, the creation and maintenance of residential districts, from which business and trade of every sort, including hotels and apartment houses, are excluded."2 The Court finds that the zoning law at issue "bears a rational relation to the health and safety of the community."3 That "rational relation" means maintenance-that government must show results, not goals, when it defends its policy-is shown when the Court approvingly cites another ruling sustaining zoning laws which preserve facts in the face of "changing conditions."

So how does government show a "rational relation?" By showing that the policy has demonstrated a "substantial relation to the public health, safety, morals, or general welfare." For the Court, public health, safety, morals, and general welfare, are not vague generalities, goals or even policies. This test makes it clear that the Court feels that what others might feel are goals - public health, safety and so on-are, perhaps, important, but the Court is concerned with important facts. The Court's question for government is, how has the policy maintained those facts? not even, how might it maintain those facts? The Court sees this as a strict test, not a lax test. Note that the test is neither minimum scrutiny (rational relation to a legitimate government purpose) nor intermediate scrutiny (substantially advances an important government purpose). It takes rational from minimum scrutiny and substantial from intermediate scrutiny, and forms a test which is

${ }^{1}$ Euclid at 386 (citation omitted).

${ }^{2} I d$., at 390 .

${ }^{3} I d$., at 391 .

${ }_{5}^{4} I d$., at 392 .

${ }^{5} I d$., at 395 . 
no part of the scrutiny regime. Note that the Euclid Court also imposes this test for adjudications under the Due Process clause of the Fifth Amendment and also under the Due Process and Equal Protection clauses of the Fifth and Fourteenth Amendments. Thus, it is very broadly based-but it is also exacting.

The Court recently overruled Euclid. The overruling was done in the takings case Tahoe-Sierra Preservation Council v. Tahoe Regional Planning Agency, 535 US 302 (2002), which concerned temporary moratoria on development in the Lake Tahoe basin. Property owners claimed that the period of the moratoria constituted a compensable taking. Instead of applying the Euclid test, the Court, to the contrary, asserted that it had always "'generally eschewed' any set formula for determining how far is too far, choosing instead to engage in 'essentially ad hoc, factual inquiries....'Indeed, we still resist the temptation to adopt per se rules in our cases involving partial regulatory takings, preferring to examine 'a number of factors' rather than a simple 'mathematically precise' formula." 6 This paves the way for the Court to sustain "permissible exercises of the police power" under the Takings Clause. ${ }^{7}$ That this is minimum scrutiny is confirmed when the Court indicates that it is done in "[t]he interest in facilitating informed decisionmaking by regulatory agencies." 8

No one knew what showing for "informed decisioningmaking" had to be made, until Justice Kennedy announced in Lawrence v. Texas that it involved important facts. Justice Scalia misread the Court's holding. In his dissent, he claimed to have found the "ground on which the Court squarely rests its holding: the contention that there is no rational basis for the law here under attack." The sodomy law should have been upheld under this standard. ${ }^{9}$ However, what the Court actually said is that the Texas sodomy law "furthers no legitimate state interest." 10 It takes legitimate from minimum scrutiny and furthers from intermediate scrutiny, and forms a test which is no part of the scrutiny regime.

This did not revive Euclid, but it did make it clear that "informed" meant that at least one entered into a litigant's examination of government purpose: liberty. And Kennedy makes it clear that it does so because "liberty" is a part of the Fifth Amendment. The indicia of liberty-whether they include Euclid facts such as housing, public health, safety, morals, or general welfare-are up to litigants to demonstrate. Kennedy doesn't provide any criteria for those-or, for that, matter, for liberty beyond the facts of Lawrence. However, he does make it clear that the inquiry into liberty is a factual inquiry: "Had those who drew and ratified the Due Process Clauses of the Fifth Amendment or the Fourteenth Amendment known the components of liberty in its manifold possibilities, they might have been more specific. They did not presume to have this insight. They knew times can blind us to certain truths and later generations can see that laws once thought necessary and proper in fact serve only to oppress. As the Constitution endures, persons in every generation can invoke its principles in their own search for greater freedom." 11 That is, he made it clear that liberty has "components." Which means that it exists—not as a goal, ideal or policy—but rather, as a fact.

${ }^{6}$ Tahoe at 327 (citations omitted).

${ }^{7} I d$., at 335 .

${ }^{8} I d .$, at 339 .

${ }^{9} 539$ US 558, $599(2003)$

${ }^{10} I d$., at 560 .

${ }^{11}$ Id., at 578-579. 
This statement helps narrow down the inquiry into government purpose. Maintenance of liberty is the purpose of government policy. How do we determine if, in fact, that is going on? Kennedy is much more specific about those criteria in Kelo v. New London, ${ }^{12}$ and he did not let either the bungling Court or the bungling litigants stop him from laying them out. In his concurring opinion, he makes it clear that just as maintenance determines whether government decisionmaking is informed, chronology goes to whether what is informed is government decisionmaking. He lays out a civil discovery program for lawyers whose clients stand to lose because government has invoked minimum scrutiny. He says, in the context of eminent domain use relying on minimum scrutiny, that lawyers should ask for evidence on the following issues in order to determine whether government has met its burden of proof. He says the Court needs to know if, in fact, there is a government purpose and he says that the Court can only do so after the Court has seen facts relating to specified criteria:

A court confronted with a plausible accusation of impermissible favoritism to private parties should [conduct]....a careful and extensive inquiry into "whether, in fact, the development plan [chronology]

[1.] is of primary benefit to ... the developer..., and private businesses which may eventually locate in the plan area...,

[2.] and in that regard, only of incidental benefit to the city....[.]'

Kennedy is also interested in facts of the chronology which show, with respect to government,

[3.] awareness of...depressed economic condition and evidence corroborating the validity of this concern...,

[4.] the substantial commitment of public funds...before most of the private beneficiaries were known...,

[5.] evidence that [government] reviewed a variety of development plans...[,]

[6.] [government] chose a private developer from a group of applicants rather than picking out a particular transferee beforehand and...

[7.] other private beneficiaries of the project [were]...unknown [to government] because the...space proposed to be built $[\mathrm{had}]$ not yet been rented.... ${ }^{13}$

It is simple enough to combine Kelo and Lawrence to derive the new minimum scrutiny. It requires litigants to

show whether the eminent domain or other land use chronology

1. is of primary benefit to another purpose than liberty,

${ }^{12} 545$ US __ (2005).

${ }^{13} I d$., at 2-3 (Kennedy, J., concurring). 
2. and in that regard, only of incidental benefit to liberty,

and whether the facts of the chronology show

3. awareness of violations of liberty and evidence corroborating the validity of this concern,

4. a substantial government liberty policy...before another purpose is known,

5. evidence that government reviewed a variety of liberty policies,

6. government chose eminent domain or land use from a range of choices rather than picking them out beforehand and

7. liberty implications were unknown to government.

These criteria provide not one, but two, opportunities to contest eminent domain use or land use policy. First, as to whether the use maintains a fact the Court already recognizes, liberty. However, they also allow litigants to challenge the dimensions of liberty drawn by government in the course of its decisionmaking. Under this new minimum scrutiny, the burden has shifted to government to demonstrate that its proposed action has, in fact, maintained liberty by forcing it to articulate liberty in that processand litigants can discover evidence of that articulation, and that factual articulation is of other facts.

We are far, indeed, from the days when those contesting eminent domain had to argue about goals or ideals! 